\title{
PEMBELAJARAN INOVATIF, KREATIF DAN PRODUKTIF SERTA IMPLEMENTASINYA DALAM MEMBANGUN KETERAMPILAN BERPIKIR TINGKAT TINGGI PESERTA DIDIK
}

\author{
Junaidin \\ Dosen Program Studi Pendidikan IPS-Geografi Univ. Muhammadiyah Mataram \\ Email : dinjunai78@yahoo.co.id
}

\begin{abstract}
ABSTRAK
Social Studies Education sangat penting dalam segala aspek kehidupan, karena itu perlu dipelajari agar semua insan Indonesia. Pendidikan Social Studies Education yang bertanggungjawab atas pengembangan keterampilan berpikir peserta didik perlu ditingkatkan kualitasnya, melalui pengembangan berpikir tingkat tinggi peserta didik. Problem-based learning (PBL) merupakan pembelajaran yang inovatif, kreatif dan produktif, karena dapat meningkatkan kemampuan siswa untuk memecahkan masalah dalam kehidupan yang makin kompleks di abad ke-21 ini. Tahap-tahap dalam PBL membimbing siswa untuk melakukan selfdirected learning, sehingga dapat membentuk kemandirian. Dalam pemecahan masalah melalui $\mathrm{PBL}$ juga dituntut pengembangan kemampuan lintas bidang studi dan kolaborasi dalam membangun pengetahuan. Di samping itu siswa juga dilatih untuk memilah dan memilih informasi yang sesuai, melakukan prediksi dan evaluasi terhadap jawaban permasalahan, yang membentuk kreativitasnya. Dengan PBL waktu belajar juga dapat digunakan secara lebih efektif, yang melalui penggunaan ICT sebagai sumber informasi, maupun ajang komunikasi lintas batas dan lintas waktu. PBL yang mengakomodasi penggunaan ICT dapat menjawab masalah kekurangan waktu belajar, keterbatasan luas dan jumlah kelas di sekolah, maupun kurangnya jumlah guru khususnya di daerah terpencil. Implementasi pembelajaran yang berbasis ICT dapat memberikan kontribusi positif dalam inovasi pembelajaran.
\end{abstract}

Kata kunci: Pembelajaran Inovatif, PBL, ICT, Berpikir Tingkat Tinggi

\section{Pendahuluan}

Pada milenium ke-3 di abad ke-21 ini bangsa Indonesia harus siap menghadapi tantangan global. Masalah-masalah global banyak dirasakan oleh bangsa Indonesia masa kini, di antaranya pertentangan antar kelompok sosial yang tak terkendali, kesenjangan yang makin besar antara pihak kaya dan miskin di dunia dan perlunya investasi besar dalam bidang intelektual manusia. Dalam hal ini bangsa-bangsa di dunia, termasuk di dalamnya bangsa Indonesia sangat bergantung pada penggunaan Social Studies Education dan teknologi secara bijaksana. Kemampuan ini bergantung pada karakter, sebaran, dan keefektifan pendidikan yang diterima masyarakat. Tujuan utama pendidikan yang diperlukan adalah mempersiapkan manusia untuk mengarahkannya dalam mengisi kehidupan secara bertanggungjawab (Liliasari, 2010).

Social Studies Education dapat
menolong peserta didik untuk
mengembangkan pemahaman dan kebiasaan berpikir yang diperlukan sebagai manusia yang memiliki tenggang rasa yang dapat berpikir untuk dirinya sendiri dan bangsanya. Pendidikan Social Studies Education juga harus mempersenjatai mereka ketika berpartisipasi menyumbangkan pemikiran dengan sesama warganegara untuk melindungi masyarakat yang sangat terbuka, sehingga dalam keadaan bahaya (Rutherford and Ahlgren, 1990).

Munculnya globalisasi ekonomi yang menandai dimulainya persaingan bebas antar bangsa di dunia, mengisyaratkan perlunya membekalkan kemampuan berpikir kreatif bagi manusia Indonesia masa depan agar dapat memenangkan persaingan tersebut. Untuk mengembangkan pola berpikir kreatif pada siswa diperlukan waktu belajar yang cukup banyak, sedangkan waktu belajar sangat terbatas; mengingat jumlah siswa juga terus bertambah pesat pada masa kini.

Keterbukaan pada berbagai bidang kehidupan telah dimulai. Sekolah yang biasanya dibatasi oleh dinding-dinding kelas dan waktu belajar, mengalami perubahan pesat dengan hilangnya batas-batas tersebut, karena perkembangan pesat information communication technology (ICT).

Berdasarkan paparan di atas maka permasalahannya adalah bagaimana pendidikan MIPA yang inovatif dapat dikembangkan untuk mengatasi tantangantantangan tersebut? 


\section{Dimensi-dimensi Pembelajaran Social Studies Education}

Bila peserta didik diperkenalkan pada hakikat Social Studies Education, biasanya menjadi bingung dan memiliki kesan bahwa Social Studies Education tidak berbeda dengan mistik atau kepercayaan yang terselubung dan biasanya dipelajari secara hafalan. Untungnya ada dimensidimensi dalam pembelajaran Social Studies Education untuk memperjelas hakikat tersebut. Dimensi-dimensi atau sudut pandang ini dapat digunakan untuk melaksanakan, dan menganalisis pembelajaran Social Studies Education. Berdasarkan kedalaman cara mempelajarinya Social Studies Education memiliki 4 dimensi, yaitu: (1) Social Studies Education sebagai cara berpikir; (2) Social Studies Education sebagai cara untuk menyelidiki; (3) Social Studies Education sebagai pengetahuan; (4) Social Studies Education dan interaksinya dengan teknologi dan masyarakat.(Chiapetta and Koballa, 2006). Perbedaan sudut pandang ini dapat mengarahkan seperti apa cara pembelajaran Social Studies Education yang dipilih. Pada hakikatnya perbedaan keempat sudut pandang tersebut dalam pelaksanaan pembelajaran Social Studies Education dalam pendidikan Social Studies Education dewasa ini dapat digambarkan seperti terlihat dalam Gambar 1.

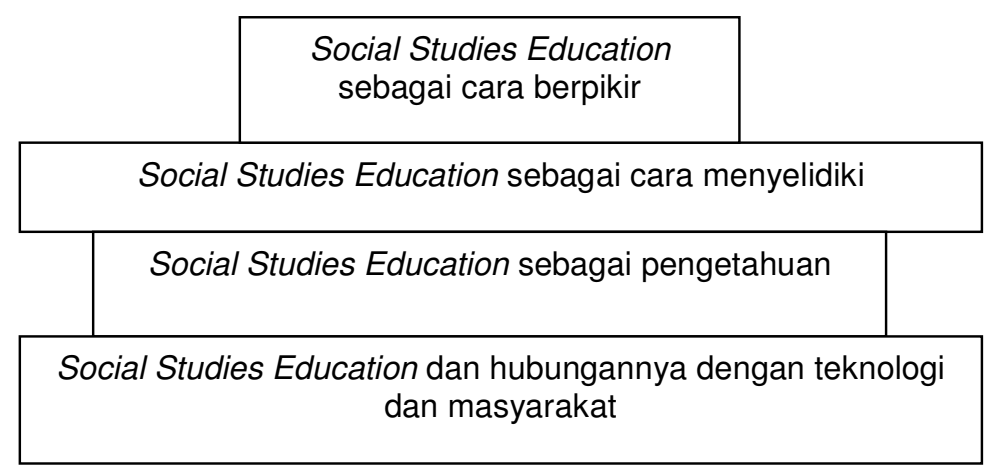

Gambar 1. Dimensi-dimensi dan intensitas pembelajaran Social Studies Education

\begin{abstract}
Belajar Social Studies Education sebagai cara berpikir meliputi keyakinan (belief), rasa ingin tahu (curiosity), imaginasi (imagination), penalaran (reasoning), hubungan sebab-akibat (cause-effect relationship), pengujian diri dan skeptis (selfexamination and skeptiscism), keobjektifan dan berhati terbuka (objectivity and openmindedness). Sebagai cara untuk menyelidiki belajar Social Studies Education dapat berupa metode ilmiah, yang titik beratnya adalah berhipotesis (hypothesis), pengamatan (observation), melakukan eksperimen (experimentation), dan menggunakan matematika (mathematics). Social Studies Education sebagai pengetahuan (body of knowledge) meliputi fakta (facts), konsep-konsep (concepts), hukum-hukum dan prinsip-prinsip (laws and principles), teori-teori (theories) dan modelmodel (models). Social Studies Education dalam interaksinya dengan teknologi dan masyarakat telah banyak dipelajari dalam
\end{abstract}

berbagai bentuk pembelajaran seperti STS, SETS, serta pembelajaran Social Studies Education kontektual seperti CTL.

Literasi Social Studies Education merupakan pengetahuan dan pemahaman konsep-konsep dan proses Social Studies Education yang diperlukan untuk pengambilan keputusan pribadi, berpartisipasi dalam kegiatan masyarakat dan budaya, serta produktivitas ekonomi. Litersi Social Studies Education juga meliputi jenis kemampuan yang spesifik (NSES, 1996). Literasi Social Studies Education berimplikasi pada kemampuan seseorang mengidentifikasi isu-isu Social Studies Education yang melandasi pengambilan keputusan lokal dan nasional yang dapat pula menunjukkan posisi Social Studies Education dan teknologi yang telah diterimanya. Dalam hal ini tersirat peranan serta kewajiban pendidikan Social Studies Education dalam membentuk warganegara yang melek Social Studies Education. 
Beberapa contoh berikut menggambarkan rendahnya literasi Social Studies Education bangsa Indonesia. Seseorang membawa petasan yang dibungkus rapat dalam bis pada siang hari yang mengakibatkan kebakaran yang mencelakakan semua penumpang bis. Pekerja papan reklame memperbaiki papan reklame tersebut dengan memanjat tiang listrik sehingga tersengat arus listrik tegangan tinggi. Penangkap belut menggunakan listrik tanpa alas kaki karet atau bahkan menceburkaan diri ke sungai sambil membawa alat penyetrum ikan tersebut. Orang menggunakan telepon genggam ketika terperangkap di lokasi yang diduga terdapat bom buku.Mahasiswa menyalakan alat-alat elektronik untuk praktikum tanpa lebih dahulu mencermati tegangan pada stop kontak yang digunakannya.Orang merasa aman berteduh di bawah pohon rindang ketika hujan berpetir atau bermain layang-layang di atas atap rumah ketika akan hujan berpetir. Masih banyak bukti-bukti lain yang dapat menjadi indikator lemahnya dampak pendidikan Social Studies Education di negara kita. Menjadi juara olimpiade saja belum tentu menjamin siswa melek Social Studies Education. Bagaimana mengatasi kesenjangan dalam pembelajaran Social Studies Education, agar tercapai literasi Social Studies Education?

\section{Pergeseran Paradigma dalam Pembelajaran Social Studies Education}

Sebagaimana dilukiskan pada gambar 1 pendidikan Social Studies Education masih terpaku pada pembelajaran 'Social Studies Education sebagai pengetahuan' dengan porsi yang berlimpah. Untuk memperbaiki kondisi tersebut, ada 5 hal yang merupakan learning gaps (Light and Cox, 2001) yang perlu diubah dalam rangka peningkatan kualitas pembelajaran, khususnya di perguruan tinggi, yaitu dari :(1) hafalan menjadi pemahaman; (2) pemahaman menjadi kemampuan (kompetensi); (3) kemampuan menjadi keinginan untuk melakukan; (4) keinginan untuk melakukan menjadi secara nyata melakukan; (5) secara nyata melakukan menjadi dalam proses berubah/ selalu berubah. Tantangan seperti ini harus segera direspon oleh setiap perguruan tinggi untuk menopang perkembangan masyarakat dalam rangka memenangkan persaingan global.

Seiring dengan berlangsungnya perubahan cara belajar tersebut, maka belajar Social Studies Education juga harus mengubah paradigma. Perubahan paradigma belajar Social Studies Education yaitu dari belajar Social Studies Education menjadi berpikir melalui Social Studies Education, yang akhirnya menjadi berpikir Social Studies Education. Belajar Social Studies Education yang sedang berlaku masa kini juga bervariasi kadarnya. Dari rentang yang paling rendah yaitu belajar Social Studies Education melalui hafalan Social Studies Education. Ini yang sangat banyak berlaku. Berdasarkan bagan pada gambar 1 disadari bahwa belajar Social Studies Education seperti ini sangatlah sukar, mengingat konten Social Studies Education sangat banyak dan bervariasi. Hal ini menyebabkan banyak peserta didik segan belajar Social Studies Education, karena dianggap sangat sulit. Padahal di pihak lain Social Studies Education sangat diperlukan yang dikenal dengan science for all,karena seluruh aspek kehidupan tidak dapat lepas dari Social Studies Education. Ini merupakan tantangan yang harus segera dijawab oleh pendidikan Social Studies Education untuk berubah dalam rangka pencapaian literasi Social Studies Education. Bagaimana realisasi jawaban terhadap permasalahan terseebut? Pembelajaran Social Studies Education perlu ditingkatkan menjadi berpikir melalui Social Studies Education, yang selanjutnya perlu berubah terus menjadi berpikir Social Studies Education. Banyak model-model pembelajaran Social Studies Education menolong kita semua untuk berpikir melalui Social Studies Education, yaitu seperti ranah ke-3 dan ke-4 dari bagan pada gambar 1, yaitu ' Social Studies Education sebagai cara menyelidiki' serta 'Social Studies Education dan interaksinya dengan teknologi dan masyarakat'. Menurut standar pendidikan Social Studies Education NSES perubahan pola pembelajaran Social Studies Education perlu mengikuti pola yang terdapat dalam Tabel 1. 
Tabel 1.

Perubahan Pola Penekanan Pembelajaran Social Studies Education (NSES, 2006)

\begin{tabular}{|c|c|}
\hline Pola Lama & Pola Baru \\
\hline $\begin{array}{l}\text { Mengenal informasi dan fakta Social Studies } \\
\text { Education }\end{array}$ & $\begin{array}{l}\text { Memahami konsep Social Studies Education } \\
\text { dan mengembangkan kemampuan inkuiri }\end{array}$ \\
\hline $\begin{array}{l}\text { Mempelajari materi subjek disiplin-disiplin } \\
\text { Social Studies Education (IPS, Geografi, } \\
\text { Ekonomi, Sosiologi, Sejarah) untuk } \\
\text { kepentingannya masing-masing }\end{array}$ & $\begin{array}{l}\text { Mempelajari materi subjek disiplin-disiplin } \\
\text { Social Studies Education dalam konteks inkuiri, } \\
\text { teknologi, Social Studies Education dalam } \\
\text { pandangan pribadi dan sosial, sejarah dan } \\
\text { hakikat Social Studies Education) }\end{array}$ \\
\hline $\begin{array}{l}\text { Memisahkan produk dan proses Social } \\
\text { Studies Education }\end{array}$ & $\begin{array}{l}\text { Mengintegrasikan semua aspek materi Social } \\
\text { Studies Education }\end{array}$ \\
\hline $\begin{array}{l}\text { Mempelajari banyak topik Social Studies } \\
\text { Education }\end{array}$ & $\begin{array}{l}\text { Mempelajari sedikit konsep Social Studies } \\
\text { Education yang fundamental }\end{array}$ \\
\hline $\begin{array}{l}\text { Menerapkan inkuiri pada seperangkat proses } \\
\text { Social Studies Education }\end{array}$ & $\begin{array}{l}\text { Menerapkan inkuiri sebagai strategi } \\
\text { pembelajaran, kemampuan, dan ide yang } \\
\text { dipelajari }\end{array}$ \\
\hline
\end{tabular}

Dalam bidang inkuiri kecenderunga perubahan pendidikan Social Studies Education dapat dilihat pada Tabel 2.

Tabel 2. Perubahan Penekanan dalam Pengembangan Inkuiri (NSES,1996)

\begin{tabular}{|c|c|}
\hline Kurang menekankan & Lebih menekankan \\
\hline $\begin{array}{l}\text { Demonstrasi atau verifikasi konsep/ materi } \\
\text { Social Studies Education }\end{array}$ & $\begin{array}{l}\text { Menyelidiki dan menganalisis pertanyaan } \\
\text { Social Studies Education }\end{array}$ \\
\hline Penyelidikan pada waktu tertentu & Penyelidikan pada waktu yang lebih luas \\
\hline Keterampilan proses di luar konteks & Keterampilan proses dalam konteks \\
\hline $\begin{array}{l}\text { Keterampilan proses individual seperti } \\
\text { mengamati, menyimpulkan }\end{array}$ & $\begin{array}{l}\text { Menggunakan keterampilan proses multipel } \\
\text { (manipulasi, prosedural, kognitif) }\end{array}$ \\
\hline Mencari jawaban & $\begin{array}{l}\begin{array}{l}\text { Menggunakan bukti } \\
\text { mengembangkan } \\
\text { penjelasan }\end{array} \\
\text { atau }\end{array}$ \\
\hline $\begin{array}{l}\text { Social Studies Education sebagai eksplorasi } \\
\text { dan eksperimen }\end{array}$ & $\begin{array}{l}\text { Social Studies Education sebagai argumen dan } \\
\text { penjelasan }\end{array}$ \\
\hline $\begin{array}{l}\text { Memberikan jawaban terhadap pertanyaan } \\
\text { tentang konsep Social Studies Education }\end{array}$ & $\begin{array}{l}\text { Mengkomunikasikan penjelasan Social Studies } \\
\text { Education }\end{array}$ \\
\hline $\begin{array}{l}\text { Individu atau kelopok siswa menganalisis dan } \\
\text { mensintesis data tanpa mempertahankan } \\
\text { kesimpulan }\end{array}$ & $\begin{array}{l}\text { Kelompok siswa sering menganalisis dan } \\
\text { mensintesis data setelah mempertahankan } \\
\text { kesimpulan }\end{array}$ \\
\hline $\begin{array}{lcc}\text { Melakukan sedikit penyelidikan untuk } & \text { un } \\
\text { memenuhi waktu yang tersedia } & \text { untuk } \\
\text { mempelajari banyak materi pelajaran } & \\
\end{array}$ & $\begin{array}{l}\text { Melakukan lebih banyak penyelidikan untuk } \\
\text { mengembangkan pemahaman, kemampuan, } \\
\text { nilai inkuiri, dan pengetahuan }\end{array}$ \\
\hline $\begin{array}{l}\text { Menyimpulkan keingintahuan dengan hasil } \\
\text { ekperimen }\end{array}$ & $\begin{array}{l}\text { Menerapkan hasil eksperimen pada argumen } \\
\text { dan penjelasan ilmiah }\end{array}$ \\
\hline Managemen materi dan peralatan & Managemen ide dan informasi \\
\hline $\begin{array}{l}\text { Komunikasi pribadi ide dan kesimpulan siswa } \\
\text { kepada guru }\end{array}$ & $\begin{array}{l}\text { Komunikasi umum ide dan karya siswa kepada } \\
\text { teman-teman sekelasnya }\end{array}$ \\
\hline
\end{tabular}


Problem Based Learning (PBL) sebagai Alternatif Baru Pembelajaran Social Studies Education

PBL merupakan pembelajaran yang dapat mengembangkan pemikiran yang kreatif dan produktif dapat menjadi alternatif pilihan untuk menjawab tantangan masa depan. Melalui PBL banyak tantangantantangan kini dan masa depan dapat dijawab.

Kekuatan suatu masalah (problem) ternyata dapat menghantarkan banyak peneliti untuk mencapai hadiah Nobel. Sebagai contoh temuan sifat antioksidan vitamin $\mathrm{C}$ oleh Albert Szent-Gyorgyi seorang ilmuwan asal Hongaria yang memenangkan hadiah Nobel bermula dari masalah " Mengapa apel dan pisang bila jatuh ke lantai sebagian mengalami kerusakan dan berubah warna menjadi cokelat, sedangkan jeruk tidak?" Para ilmuwan tertantang untuk mencari jawaban terhadap masalah tersebut yang dikenal sebagai " masalah pisang".

Untuk memecahkan masalah tersebut Szent-Gyorgyi mulai berpikir dengan cara membandingkan, mengklasifikasikan, mengamati dan menghubung-hubungkan informasi-informasi kunci dalam bidang biologi dan kimia. Mula-mula ia mengelompokkan buah-buahan menjadi kelompok yang mengalami pencokelatan dan yang tidak mengalaminya. la menyimpulkan bahwa bila jaringan tumbuhan atau buahbuahan rusak, maka senyawa polifenol yang terkandung di dalamnya bereaksi dengan oksigen menghasilkan senyawa berwarna cokelat. Mengapa pada buah jeruk hal itu tidak terjadi? Jeruk mengandung senyawa lain yang dapat mencegah terjadinya oksidasi, yaitu vitamin C. Dengan adanya vitamin $\mathrm{C}$ reaksi polifenol dengan oksigen dihalangi sehingga tidak terjadi.

Temuan ini ternyata berdampak luas pada bidang kesehatan, yang menghantarkannya memperoleh hadiah Nobel dalam bidang fisiologi dan kesehatan. Ilustrasi tersebut menunjukkan betapa besarnya makna sebuah masalah, yang umum terjadi dalam kehidupan sehari-hari dan biasanya dianggap sepele. Betapa ilmuwan dapat terbius oleh masalah sederhana tersebut dan memaknainya secara serius sebagai suatu tantangan yang harus ditaklukkan.Pengalaman SzentGyorgyi menunjukkan bahwa masalah mempunyai " kekuatan dan daya tarik" yang hebat untuk menciptakan suasana belajar yang tidak menjemukan.

Sebagian besar pembelajaran biasanya dilakukan melalui hafalan, peniruan, dan pemodelan. Yang disebut " masalah" dalam cara belajar tersebut biasanya adalah sejumlah latihan memecahkan soal-soal. Di kelas para guru memberikan banyak contoh dengan panduan yang lengkap dan langkah-langkah pemecahan yang berurutan. Siswa diberi latihan masalah-masalah yang serupa atau sedikit bervariasi, juga melakukan langkahlangkah yang sama dengan yang diajarkan guru, sehingga tidak mungkin ada keaslian pendapat siswa. Struktur pembelajaran seperti itu dapat dilukiskan seperti Gambar 2.

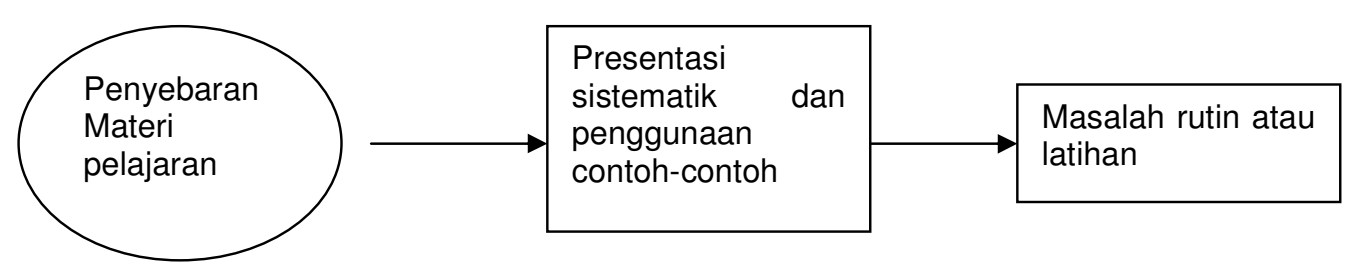

Gambar 2. Representasi struktur pembelajaran konvensional

Struktur pembelajaran seperti pada gambar 2 akan sangat membosankan dan tidak menarik, karena siswa dibuat terlalu lelah dengan jumlah pengetahuan yang disampaikan guru yang semakin banyak pada era informasi ini. Agar pembelajaran menjadi lebih menarik dan menantang bagi siswa, perlu perubahan strategi pembelajaran dengan mengemukakan masalah-masalah yang perlu dipecahkan siswa. Sebaran masalah dalam pembelajaran dapat dilihat pada Gambar 3. 


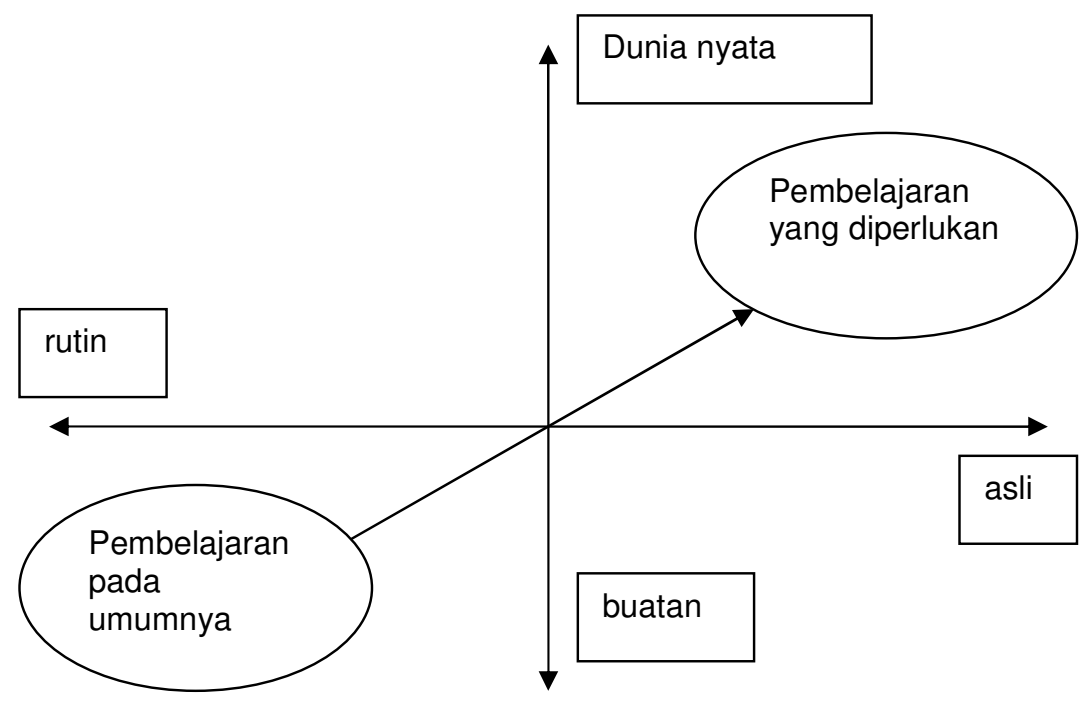

Gambar 3. Bentuk masalah dalam kurikulum

Berdasarkan Gambar 3 masalah yang sangat efektif dikemukakan dalam pembelajaran yaitu masalah yang asli dan terdapat dalam dunia nyata, bukan masalah buatan yang rutin dikemukakan dalam pembelajaran konvensional. Dalam memecahkan masalah di dunia nyata kita perlu menyadari bahwa seluruh proses kognitif dan kegiatan mental dilibatkan. Otak kita akan menempuh siklus dan pengulangan berpikir secara sistematik, sistemik, generatif, analitik dan divergen.

Pembelajaran yang berbasis masalah dalam kehidupan nyata disebut PBL. Pembelajaran ini menjadi penting, karena masalah yang dikemukakan banyak dan sulit. Akibatnya bila seseorang berlatih memecahkan masalah, maka waktu yang digunakan untuk memecahkan masalah baru menjadi lebih singkat dari pada sebelumnya.
Makin global masalah-msalah yang dikemukakan, akan makin memerlukan pemecahan yang terpadu secara berkolaborasi. Ada tiga hal penting dalam PBL ( Tan,2003), yaitu: (1) pemahaman diturunkan dari interaksi skenario masalah dengan lingkungan belajar; (2) keterikatan dengan masalah dan proses inkuiri masalah membentuk disonansi kognitif yang mendorong belajar; (3) pengetahuan yang terbentuk telah melalui proses kolaboratif, negosiasi dan evaluasi sosial yang dilihat dari sudut pandang seseorang. Jadi berdasarkan perspektif pedagogi, PBL dibangun berlandaskan teori belajar konstruktivis.

Perubahan paradigma belajar berdasarkan PBL dibandingkan dengan pembelajaran konvensional dapat dilihat pada Gambar 4.

Sistem pendidikan sekarang

Sistem pendidikan yang lebih berorientasi dunia nyata
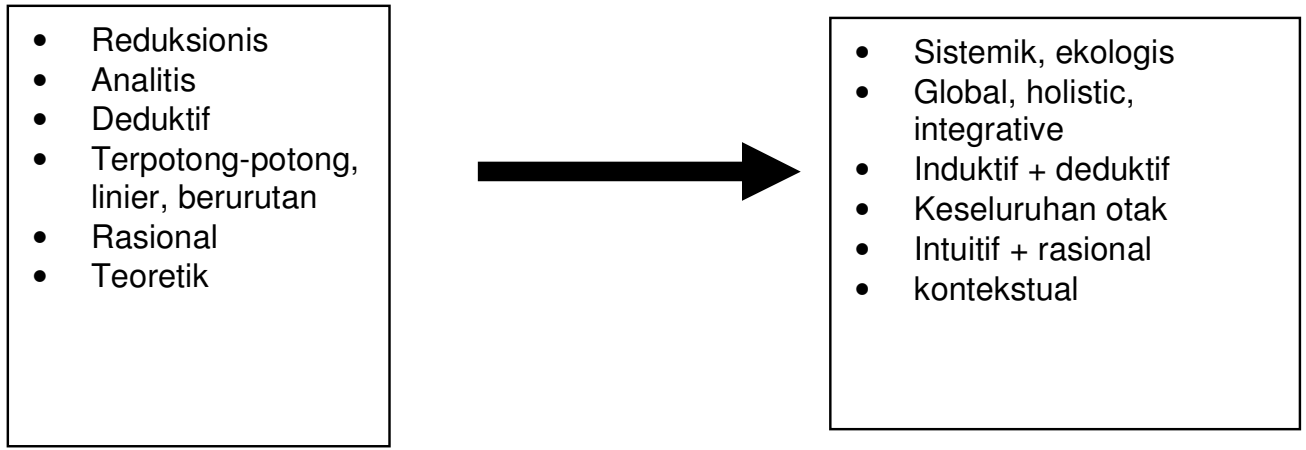

Gambar 4. Pergeseran paradigma dalam sistem pendidikan 


\section{Apakah dan bagaimana PBL?}

Tujuan $P B L$ sesungguhnya adalah belajar materi, pencarian hubungan antar disiplin dan pengembangan keterampilan pemecahan masalah. PBL juga mengandung tujuan mengatur pembelajaran secara mandiri dalam kehidupan secara luas, mengembangkan keterampilan memilah dan memilih informasi, belajar kolaboratif dalam tim, keterampilan berpikir reflektif dan evaluatif. Penerapan prinsip-prinsip $P B L$ dalam kurikulum sekolah secara umum dapat dilihat pada Gambar 5.

Pada mulanya alasan penggunaan PBL pada sekolah-sekolah di Amerika
Serikat meliputi nilai-nilai: (1) penggunaan isu-isu kehidupan nyata; (2) hubungan aktif; (3) pembelajaran interdisiplin; (4) siswa menentukan pilihan dalam pembelajaran; (5) belajar kolaboratif. Hal ini ternyata cocok dipilih untuk diterapkan di Indonesia dalam rangka meningkatkan kualitas pembelajaran yang menekankan pada pemecahan masalah dan berpikir. Penelitian West (1992) menemukan bahwa PBL di sekolah menengah dapat memicu timbulnya minat terhadap Social Studies Education, meningkatkan pembentukan pengetahuan dan memperbaiki keterampilan pemecahan masalah.

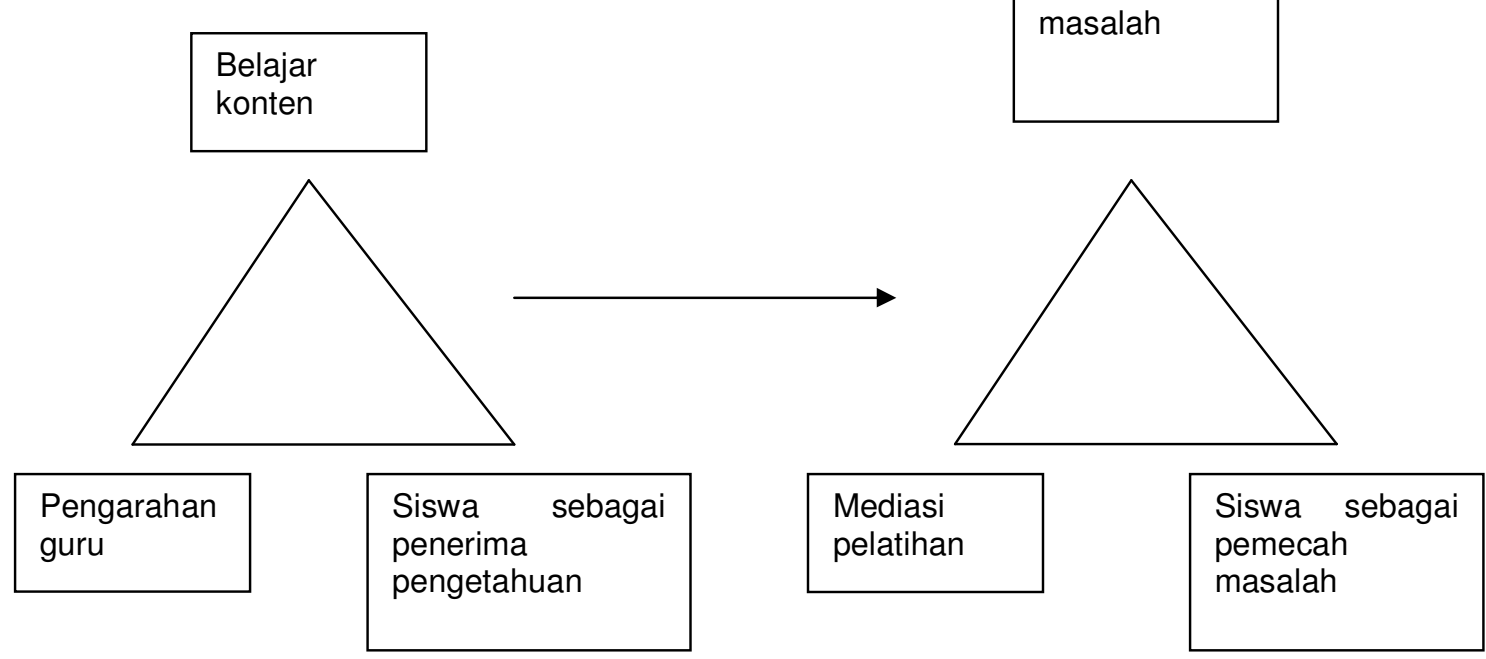

\section{Gambar 5. Model perubahan kurikulum}

Beberapa sifat khusus PBL menurut Tan (2002) yaitu: (1) masalah merupakan titik awal pembelajaran; (2) masalah biasanya adalah masalah dalam dunia nyata, yang muncul tak terstruktur; (3) masalah memerlukan pandangan multipel, sehingga pengetahuan antar disiplin sebagai gambaran kunci dalam banyak PBL dan pemecahannya mempertimbangkan pengetahuan dari berbagai subjek dan topik; (4) masalah menantang pengetahuan, sikap dan kemampuan terkini siswa, jadi mencari kebutuhan dan area belajar baru bagi siswa; (5) mengutamakan self-directed learning yang membebankan tanggung jawab utama pada siswa untuk mencari informasi dan pengetahuan; (6) proses pembelajaran tersusun oleh berbagai sumber pengetahuan, yang dalam pemilihan, dan penggunaan sumber-sumber informasi telah dievaluasi terlebih dahulu oleh siswa; (7) pembelajaran dilakukan secara kolaboratif, komunikatif dan kooperatif dalam kelompok kecil; (8) pengembangan inkuiri dan keterampilan pemecahan masalah sama pentingnya dengan perolehan pemecahan masalah, sehingga dalam PBL guru memfasilitasi dan melatih melalui pertanyaan 
dan latihan kognitif; (9) penutup proses PBL adalah sintesis dan integrasi belajar, yang juga meliputi evaluasi dan rangkuman pengalaman dan proses pembelajaran siswa.

Komponen pembelajaran melalui PBL meliputi presentasi masalah, pemicu inkuiri masalah, tahap-tahap PBL, pemecahan masalah, presentasi dan evaluasi. Komponen-komponen tersebut dapat dilihat pada Gambar 6.

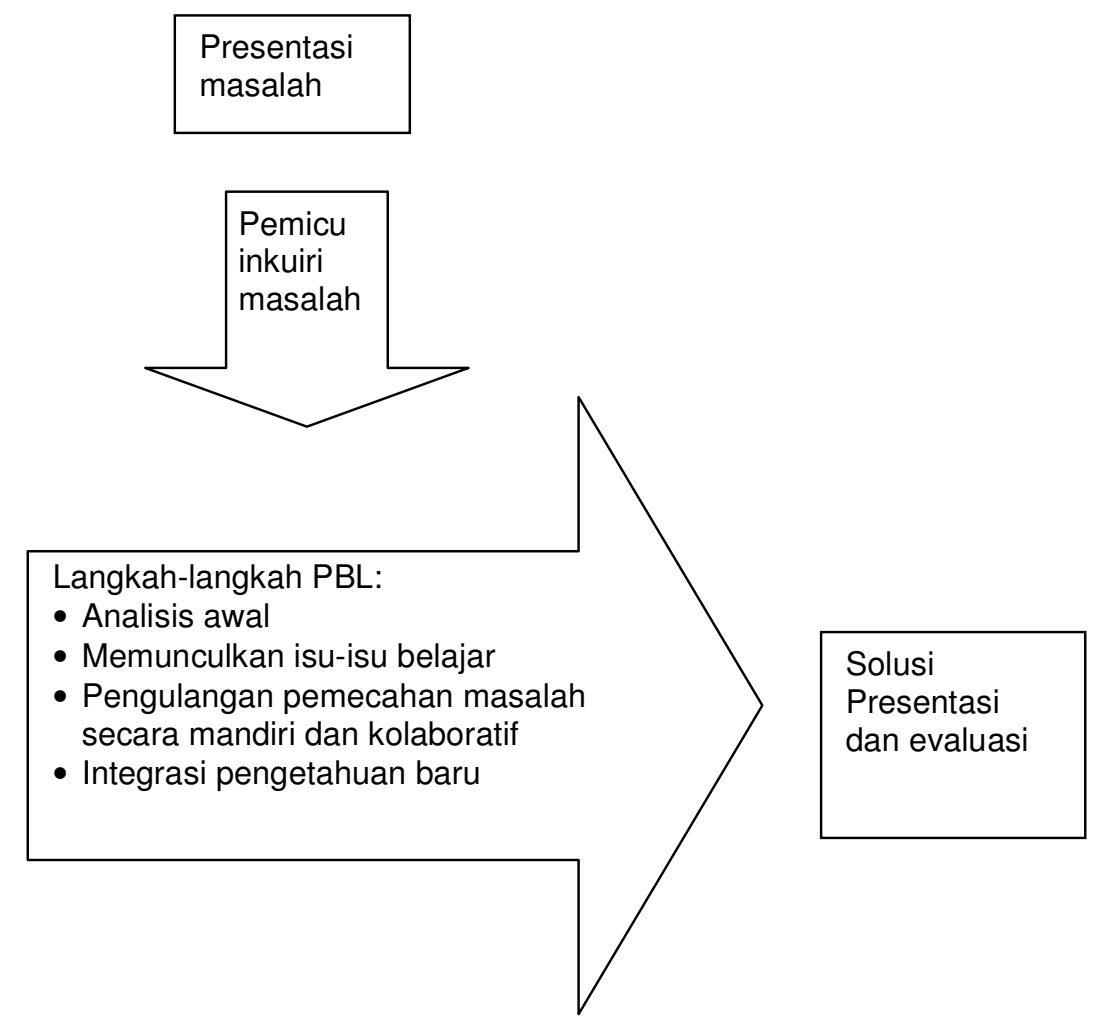

Gambar 6. Komponen-komponen PBL

Presentasi masalah merupakan tahap awal dan utama dari PBL. Masalah dikemukakan oleh guru untuk dipecahkan siswa. Masalah harus bersumber dari kehidupan nyata (kontektual). Sebagai contoh masalah:

Kamu dan beberapa orang kawan akan memulai bisnis mendesain Web pages untuk klien pengguna. Kalian memiliki beragam kemampuan pemrograman berbasis Web. Masing-masing kalian setuju memberikan 2 juta rupiah sebagai dana awal bisnis tersebut. Bagaimana kalian mendaftarkan dan memulai bismis ini?

Selanjutnya diberikan pemicu inkuiri masalah dengan cara menugaskan kepada siswa untuk mendefinisikan masalah, menganalisis masalah, mengemukakan ide atau hipotesis, dan mengidentifikasi isu-isu pembelajaran. Siswa diberi cukup waktu secara individual melakukan hal-hal tersebut. Masing-masing mereka didorong untuk menemukan kata kunci, mengemukakan ideide dan pertanyaan-pertanyaan yang muncul dalam pikiran mereka, sebelum mereka dikelompokkan.

Setelah mereka dirasakan cukup siap memecahkan masalah oleh guru, maka mulai dibentuk kelompok-kelompok kecil untuk memasuki tahap-tahap dalam pembelajaran PBL yang meliputi: meliputi analisis awal dan pembentukan isu-isu pembelajaran, pengulangan pemecahan masalah secara mandiri dan kolaboratif, integrasi pengetahuan baru, presentasi dan evaluasi.

Pada tahap analisis awal dan pembentukan isu-isu pembelajaran siswa 
dikelompokkan dalam 3-4 orang per kelompok untuk mendiskusikan skenario pemecahan masalah. Dalam hal ini dapat dikemukakan beberapa pertanyaan, misalnya:

- Apa tujuan perusahaan kita?

- Apa yang harus kita ketahui tentang berbagai macam unit-unit bisnis?

- Akankah perusahaan itu menjadi perseroan terbuka atau perseroan terbatas?

- Apakah persyaratan legalnya?

- Bagaimana kita akan mendaftarkan bisnis tersebut?

Siswa melakukan curah pendapat dalam diskusi dan berbagi tugas untuk memecahkan masalah. Dalam hal ini tujuan pembelajaran dinyatakan dalam bentuk pertanyaan-pertanyaan seperti:

- Apakah berbagai macam unit bisnis itu?
- Apakah jenis unit-unit bisnis cukup untuk mencapai tujuan bisnis itu?

- Apakah keuntungan dan kerugian dalam perseroan terbuka dibandingkan dengan perseroan terbatas?

- Apakah persyaratan legal yang berhubungan dengan pendaftaran bisnis tersebut?

Setiap siswa dalam kelompok memiliki tugas masing-masing untuk mencari jawaban terhadap pertanyaan-pertanyaan yang muncul dan mendiskusikan laporan hasil pekerjaannya kepada rekan-rekan sekelompoknya untuk menyusun laporan hasil pemecahan masalah yang akan dipresentasikan oleh kelompok. Dalam hal ini mereka membangun kerjasama, memilih dan mengintegrasikan berbagai informasi yang diperoleh, serta mengevaluasi sendiri hasil pekerjaan baik individual maupun kelompok. Secara lengkap proses PBL dapat dilihat pada Gambar 7.

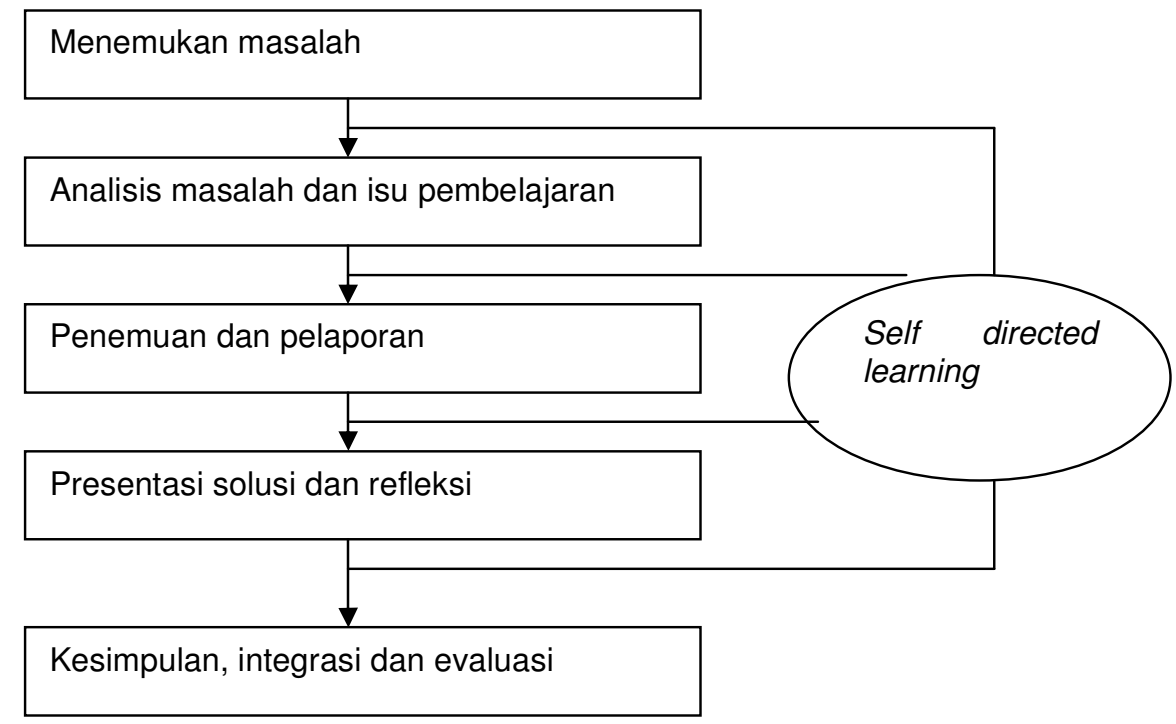

Gambar 7. Proses pembelajaran PBL

\section{PBL dan pemanfaatan Information Communication Technology (ICT)}

Seperti kita ketahui ICT berkembang pesat dan internet menyediakan informasi yang tidak terbatas jumlah dan ragamnya. Hal ini sangat sejalan dengan karakteristik PBL yang kompleks. Sehubungan dengan hal tersebut sangatlah bermanfaat bila kita menggunakan ICT dalam pembelajaran PBL sebagai inovasi pendidikan, yang sekaligus meningkatkan kualitas pembelajaran.
Keunggulan ICT dalam komunikasi dan mengakses informasi misalnya e-mail, World Wide Web, telekomunikasi internet, video conferencing sangatlah nyata. Bilamana keunggulan tersebut dikaitkan dengan PBL yang memberdayakan siswa mengambil keuntungan memperkaya pengetahuannya, dapat juga ICT mendukung dalam berbagi pengetahuan, pertumbuhan pengetahuan, serta pengumpulan pengetahuan, melalui LMS (learning 
management systems), Web-based learning, dan komunikasi internet.

Penggunaan ICT dalam PBL membantu mempercepat pemecahan masalah, karena siswa belajar menembus batas ruang dan waktu. Dalam hal ini akan dapat mengatasi kekurangan waktu belajar, ruang kelas, jumlah guru, sehingga meningkatkan kepuasan belajar siswa. Bahan-bahan ICT yang digunakan dapat berupa games, simulations, interactive multimedia software, virtual laboratory, virtual world (Aldrich, 2009).
Untuk memfasilitasi proses PBL perlu dipersiapkan membuat sumber informasi yang on-line 24 jam yang meliputi: homepage PBL, tujuan pembelajaran, struktur pembelajaran, portofolio skenario masalah, siklus PBL dan alat-alat inkuiri, panduan untuk tutor, panduan untuk siswa, sumber bahan dan hubungan-hubungan (links), criteria asesmen, serta sistem komunikasi. Sebagai wadah system komunikasi dapat digunakan LMS yang bagannya tertera dalam Gambar 8.

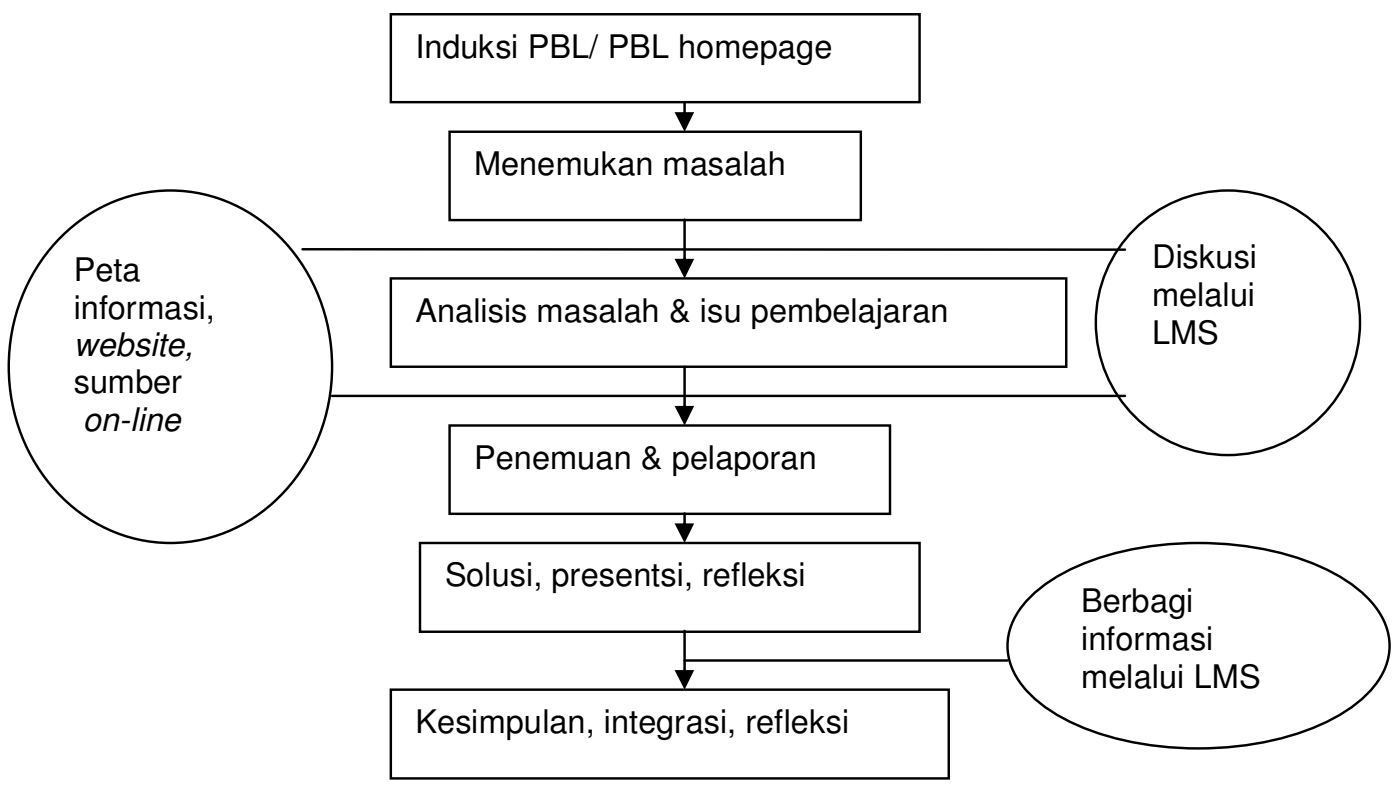

Gambar 8. Penggunaan LMS dalam PBL

\section{Implementasi Model Pembelajaran Berbasis ICT}

Model pembelajaran berbasis ICT yang digunakan adalah model pembelajaran "Elektrolisis"untuk meningkatkan penguasaan konsep dan berpikir kritis mahasiswa calon guru kimia.. Model ini diimplementasikan pada perkuliahan Kimia Sekolah di semester ke tiga. di Jurusan Pendidikan Kimia di salah satu LPTK di Bandung.
Metode yang digunakan meliputi kuasi eksperimen control group pre-posttest design. Dalam kelas eksperimen, perkuliahan dilakukan menggunakan multimedia interaktif, sedangkan dalam kelas kontrol menggunakan media powerpoint. Jumlah mahasiswa dari kelas eksperimen adalah 30 orang, dan dari kelas kontrol adalah 34 orang, Pre tes dan pos tes masing-masing dilakukan pada tanggal 13 Sept 2012 dan 2 Okt 2012 pada perkuliahan Kimia Sekolah Sebagai hasil penelitian diperoleh data seperti pada Gambar 9. 


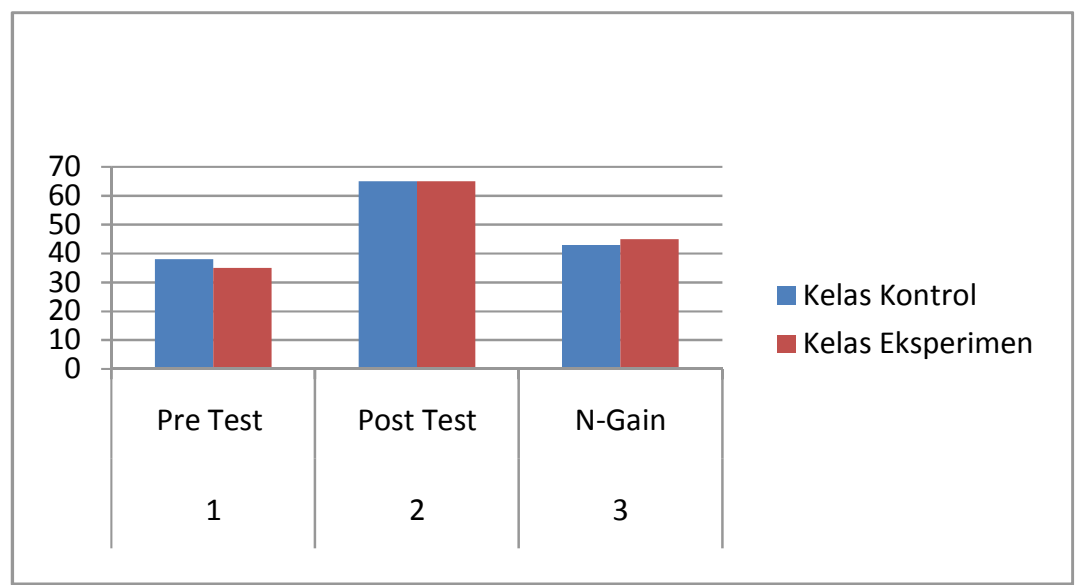

Gambar 9. Persentase Pencapaian Skor Rata-Rata Pretes, Postes dan N-gain pada topik Elektrolisis

Gambar 9 menunjukkan N-gain penguasaan konsep mahasiswa pada kelas eksperimen lebih tinggi dari pada kelas kontrol. Pemahaman konsep ini juga diikuti dengan pemahaman representasi submikroskopik terhadap konsep-konsep yang relevan seperti dapat dilihat pada tabel 3. Selanjunya capaian keterampilan berpikir kritis mahasiswa calon guru dapat dilihat pada Gambar 10

Tabel 3. Data Pretes, Postes, dan N-Gain Pemahaman Representasi Submikroskopik (PRS)

\begin{tabular}{|c|c|c|c|c|c|c|c|}
\hline \multirow{2}{*}{ NO } & \multirow{2}{*}{ PRS } & \multicolumn{3}{|c|}{ Kelas Kontrol } & \multicolumn{3}{c|}{ Kelas Eksperimen } \\
\cline { 2 - 8 } & & Pretest & Post test & N-Gain & Pretes & Post tes & N-Gain \\
\hline 1 & PRS 1 & 64 & 91 & 0,19 & 62 & 85 & 0,32 \\
\hline 2 & PRS 2 & 45 & 69 & 0,24 & 38 & 62 & 0,35 \\
\hline 3 & PRS 3 & 36 & 83 & 0,66 & 45 & 79 & 0,51 \\
\hline 4 & PRS 4 & 24 & 44 & 0,20 & 21 & 48 & 0,32 \\
\hline 5 & PRS 5 & 41 & 62 & 0,30 & 33 & 69 & 0,39 \\
\hline 6 & PRS 6 & 34 & 57 & 0,19 & 33 & 65 & 0,15 \\
\hline 7 & PRS 7 & 32 & 69 & 0,46 & 27 & 60 & 0,43 \\
\hline
\end{tabular}

Keterangan:

PRS1: Pergerakan elektron dalam sel elektrolisis, PRS2: pergerakan ion dalam sel elektrolisis, PRS 3:reaksi reduksi dalam sel elektrolisis, PRS4:reaksi oksidasi di anode, PRS5:reaksi redoks pada elektroda inert, PRS 6: reaksi redoks pada elektroda tak inert,

PRS 7: proses penyepuhan 


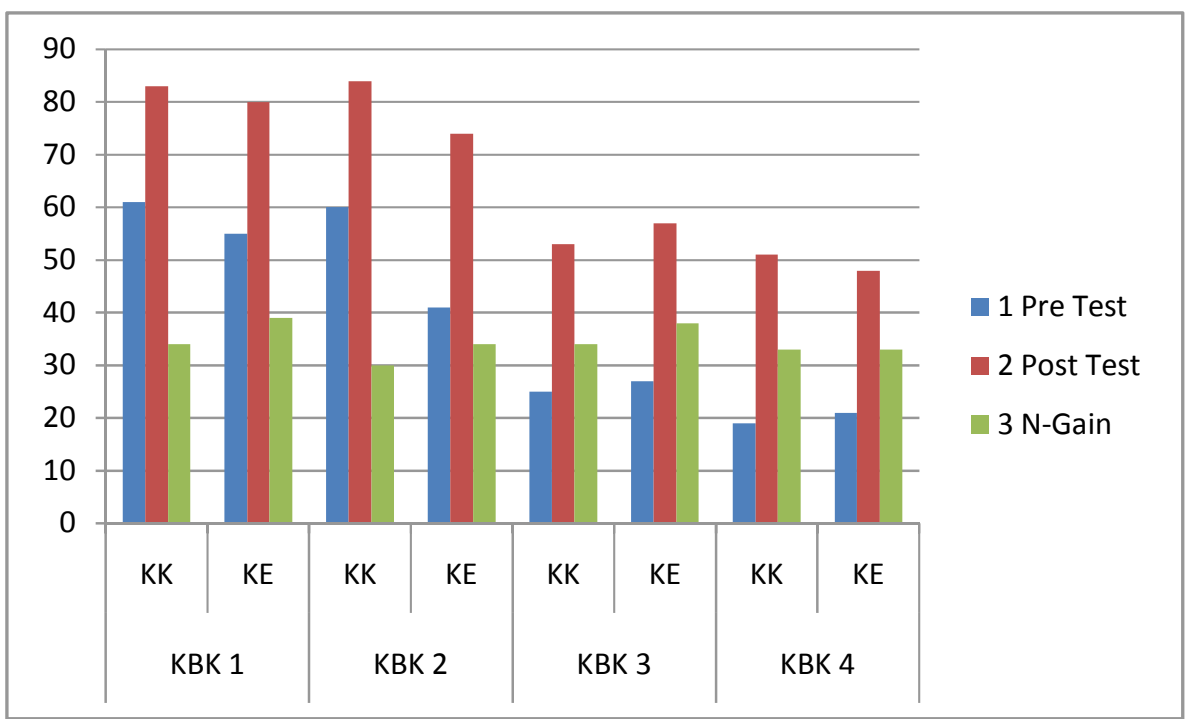

Gambar 10. Perbandingan N-gain keterampilan berpikir kritis untuk setiap indikator antara kelas eksperimen dan kelas kontrol

Hasil implementasi pembelajaran berbasis ICT menunjukkan bahwa pembelajaran tersebut lebih baik meningkatkan pemahaman konsep yang diikuti dengan pemahaman representasi submikroskopik konsep-konsep yang relevan, serta keterampilan berpikir kritis mahasiswa dapat meningkat.

\section{Simpulan}

Sebaliknya penggunaan PLB dalam e-learning dapat memotivasi hubungan online, baik dalam hal keterhubungan dengan sumber belajar, sejawat dan pakar.

1. Social Studies Education berperan sangat penting dalam segala aspek kehidupan manusia, karena itu sangat diperlukan oleh semua insan Indonesia (science for all) dalam membentuk masyarakat yang literasi Social Studies Education.

2. Strategi pembelajaran $\mathrm{PBL}$ yang terbaik adalah dengan memanfaatkan ICT dan menggunakan e-learning. Lingkungan e-learning ini sangat sempurna untuk siklus-siklus PBL., pengembangan berpikir Social Studies Education dan memberikan dampak iringan perkembangan kemampuan berpikir tingkat tingginya

3. Melalui pembelajaran Social Studies Education berbasis ICT dapat dilakukan sekaligus pengembangan penguasaan konsep Social Studies Education dan keterampilan berpikir tingkat tinggi peserta didik, termasuk di dalamnya pemahaman submikroskopik konsep

\section{Daftar Pustaka}

Aldrich, C.(2009).Learning Online with Games, Simulations, and Virtual Worlds: Strategies for Online Instruction, San Francisco: JosseyBass A Wiley Imprint

Bouhuijs. Et al (1993) Problem-based Learning as an Educational Strategy. Maastrich: Network Publications

Brotosiswoyo, B.S. (2000). Kiat Pembelajaran MIPA dan Kiat Pembelajaran Fisika di Perguruan Tinggi, Jakarta: Departemen Pendidikan Nasional

Chiapetta and Koballa ( 2006). Science Instruction in the Middle and Secondary Schools: Developing Fundamental Knowledge and Skills for Teaching, sixth edition, New Jersey: Pearson Education, Inc.

Liliasari (2005) Membangun keterampilan berpikir manusia Indonesia melalui pendidikan Social Studies Education, Pidato pengukuhan Jabatan Guru Besar Tetap dalam IImu Pendidikan IPA pada FPMIPA UPI (2010) Pengembangan berpikir kritis sebgai karakter bangsa Indonesia melalui pendidikan Social Studies Education berbasis ict, Potret Profesionalisme Guru dalam 
Membangun Karakter Bangsa: Pengalaman Indonesia dan Malaysia, Bandung: UPI

(2012) Implementasi pembelajaran berbasis ICT untuk meningkatkan keterampilan berpikir mahasiswa, Laporan Penelitian, Bandung: UPI

Moore and Parker (2009) Critical Thinking, New York: McGraw-Hill Co. Inc.

NSES (1996) National Science Education Standard, Washington, DC: National Academy Press

Nursa'adah, Euis (2011) Pembelajaran Elektrolisis Berbantuan Multimedia untuk Meningkatkan Pemahaman Representasi Submikroskopik, Keterampilan Generik Social Studies Education, dan Keterampilan Berpikir Kritis Mahasiswa Calon Guru Kimia, Tesis, Bandung: SPs UPI.

Tan, Oon-Seng. (2003). Problem-based Learning Innovation: Using problems to power learning in the $21^{\text {st }}$ century, Singapore:Thomson Learning Pte Ltd.

(2002). Problem-based learning: more problems for teacher education. Review of Educational Research and Advances for Classroom teachers, 21, 43-55. 